\title{
Punishments To Strengthen Students' Discipline for Future Education
}

\author{
Syamsuar Abbas \\ Universitas Negeri Padang \\ Padang, Indonesia \\ syamsuar90@gmail.com
}

\author{
Reflianto Reflianto \\ Sekolah Tinggi Ilmu Tarbiyah Syekh Burhanuddin \\ Pariaman, Indonesia \\ refliantomuslim@gmail.com
}

\begin{abstract}
The aim of this study was to measure students respon about the execution of applied punishment by the school, the types of punishment was taken in order to enforce the children discipline and given the punishment effect on the progress of elementary students discipline at Elementary School for their education in the future. The ways of punishment was taken by the school refere to educative punishment and age-compromised by using an effective school practice in prevailing the punishment standard for childrens. The approach of this research was quantitative with survey method. The research instrument used questionnaire, interview and documentation. Analysis of the data is inferential stantistical of regression test. The results showed that the execution of punishment can strengthening students' discipline and gave positive effect to the continuity their education in the future. The implications of study for teachers are to execute the punishment for students who violate the discipline rule as suitable as their infringement of rule by using particular technique in the form of educative punishment with agecompromised which gradually enable to improve their future education discipline.
\end{abstract}

Keywords—punishment; discipline; children; education

\section{INTRODUCTION}

Punishment in education serves as an educational tool is an action of educator that is not pleasant for the students. Such actions are carried out as a sanction or irregularities committed protégé of the provisions that have been set, with the expectation that students do not repeat the mistakes in their act. According Apriliya[1] violations and mistakes were made by learners need to be implemented by various approaches in the management of class, for example; 1) Modify the behavior of students, 2) Creating a positive socio-emotional climate, 3) Management of certain groups and 4) a combination of the three approaches. One establishment enforce discipline in the classroom management is providing motivation and punishment. Punishment becomes something that must exist in a learning process when any form of discipline and rules are violated. On the other side of motivation is also an important thing to energize learners, nourish compassion, sensitize students will be mistakes, develop a harmonious relationship with the students and are able to form good manners to the students as well as respecting and honoring the teachers so that the authority of permanent teachers maintained.

Schools' administrators and educators believe that discipline is needed in schools if the aim is to produce well educated and disciplined pupils. According to this argument discipline is necessary to provide obedience to school rules and correcting pupils misbehaviors. This is why many believers of punishment in school find a link between corporal punishment as a means of managing pupils' problems on one hand and school's discipline on the other hand[2]. In this regard many theorists attempted to define school discipline and punishment, for instance, Rosen[3] defined school discipline as a branch of knowledge-training that develops self control, character, efficiency to enforce obedience and compliance to school authority and rules and in this context corporal punishment is used by some teachers to cause physical pain on the learners to correct their misbehaviors and maintain school discipline.

From a psychological point of view Skinner who was one of the famous behavioral learning theorists' defined punishments as unpleasant and painful events (stimuli) if administered after the occurrence of certain behavior will decrease the likelihood of that behavior to occur again. Punishment takes different forms and types, however he does not advise the use of punishment as a technique of controlling/ correcting unwanted behaviors as it causes harm on the person being punished and produces negative emotions and future behavioral problems[4].

In fact, the implementation of the punishment in schools often mistaken, which adversely affects to the learners and often given the punishment do not make the learners to be deterrent to remake the same mistakes. These make the achievement of the education objectives is unoptimal, in addition to the punishment also misses the point because teachers lack an understanding of the principles of sentencing through pedagogical of class management, as mentioned above. The purpose of this study was to measure students' perceptions about the sentence being applied to the school, the type of disciplinary action taken in order to enforce discipline children 
and influence of punishment toward the progress of discipline education to the students of SDN 06 Nan Sabaris Padang Pariaman for the future.

\section{LITERATURE REVIEW}

\section{A. Discipline}

Discipline can be defined as the individual's withdrawal from undesired behaviors to perform the desired behaviors[5] To put it in another way, discipline is used in the meaning of "order" "regularity", too[6]. One of the roles of teachers in classroom is to ensure classroom discipline. The use of expression "order" is considered more appropriate. As the key of effective classroom management[7], teachers are required to have knowledge of the terms and theories related to discipline.

According to Lewis[8][9], discipline is generally represented as what teachers do in response to students ${ }^{\text {ee }}$ misbehavior. There are at least three main approaches to classroom discipline, each advocating particular techniques[8];[9]. Some educationalists argue that in order to promote responsibility in children, teachers need to develop clear expectations for student behavior and then judiciously apply a range of rewards and recognitions for good behavior as well as punishments for misbehavior[10][11]. Others argue that the aim can only be attained by less emphasis on student obedience and teacher coercion, and more on student self-regulation. This is facilitated by techniques such as negotiating, discussing, and contracting[12][13][14]. The third orientation favors group participation and decision making, whereby the group takes responsibility for ensuring the appropriateness of the behavior of all its members[14][15].

\section{B. Punishment}

Punishment is the authoritative imposition of an undesirable or unpleasant outcome upon a group or individual, in response to a particular action or behavior that is deemed unacceptable or threatening to some norm[16].

The unpleasant imposition may include a fine, penalty, or confinement, or be the removal or denial of something pleasant or desirable. The individual may be a person, or even an animal. The authority may be either a group or a single person, and punishment may be carried out formally under a system of law or informally in other kinds of social settings such as within a family[17][18]. Negative consequences that are not authorized or that are administered without a breach of rules are not considered to be punishment as defined[19].

The study and practice of the punishment of crimes, particularly as it applies to imprisonment, is called penology, or, often in modern texts, corrections; in this context, the punishment process is euphemistically called "correctional process"[20].
Research into punishment often includes similar research into prevention.

Justifications for punishment include retribution, deterrence, rehabilitation, and incapacitation. The last could include such measures as isolation, in order to prevent the wrongdoer's having contact with potential victims, or the removal of a hand in order to make theft more difficult[17][18]. Of the four justifications, only retribution is part of the definition of punishment and none of the other justifications is a guaranteed outcome, aside from obvious exceptions such as an executed man being incapacitated with regard to further crimes[19].

If only some of the conditions included in the definition of punishment are present, descriptions other than "punishment" may be considered more accurate. Inflicting something negative, or unpleasant, on a person or animal, without authority is considered revenge or spite rather than punishment. In addition, the word "punishment" is used as a metaphor, as when a boxer experiences "punishment" during a fight. In other situations, breaking a rule may be rewarded, and so receiving such a reward naturally does not constitute punishment. Finally the condition of breaking (or breaching) the rules must be satisfied for consequences to be considered punishment ${ }^{19}$.

\section{METHOD}

Method of research was a quantitative survey study namely research on data collected and expressed in the form of ideas and analysis them in the form of inferential statistic to describe in depth the situation under study by using questionnaire.

Population of this research was students class IV, V and VI at SDN 06 Nan Sabaris Padang Pariaman with 40 samples. Sample taking by stratified random sampling.

Data were collected through observation of students' perception about educative-preventive and repressive punishment and students' discipline to support their education for the future by using questionnaire, Interview and documentation

Analysis of the qualitative data was done by measuring of total of students' achievement responses in answering of questionnaire by using a formula.

$P=\underline{\mathrm{f}} \times 100$

Description :

$\mathrm{P}=$ percentage

$\mathrm{f}=$ frequency

$\mathrm{N}=$ the number

Inferential analysis used regression analysis. Regression analysis examines the situation where a dependent variable is simultaneously influenced by a number of dependant variables. $\mathrm{R}$ square value close to one indicates that the model fits the data very well. However, above 0.5 has been considered significant. 
Beta is an attempt to make the regression coefficient more comparable. The analysis of variance (ANOVA) table provides details of the variation explained by the regression model compared with the unexplained variation.Two steps of regression analysis pre-condition are Normality Test and Homogenity test.

\section{FINDING AND DISCUSSION}

\section{Characteristics of Respondents}

This research was conducted at SDN 06 Nan Sabaris Padang Pariaman. Characteristics of respondents in this study were students of class IV, V and VI with grading and gender as follows:

1) Characteristics of Respondents by Class

Profile of respondents by class is as follows:

TABLE 1. COMPOSITION OF RESPONDENTS BY CLASS

\begin{tabular}{|c|c|c|}
\hline Class & Amount & Percentage (\%) \\
\hline IV & 10 & 23.3 \\
\hline V & 11 & 30.2 \\
\hline VI & 19 & 46.5 \\
\hline Total & $\mathbf{4 0}$ & $\mathbf{1 0 0}$ \\
\hline
\end{tabular}

Sources: primary data is processed, 2016

From Table 1. It seems that the most dominant respondent was class VI many as 19 students $(47.5 \%)$, while the smallest group of fourth grade as many as 10 students $(25.0 \%)$.

2) Characteristics of Respondents by Gender Profile of respondents by sex are the following:

TABLE 2. COMPOSITION OF RESPONDENTS BY GENDER

\begin{tabular}{|c|c|c|}
\hline Gender & Amount & Percentage (\%) \\
\hline Male & 18 & 53.5 \\
\hline Female & 22 & 46.5 \\
\hline Total & $\mathbf{4 0}$ & $\mathbf{1 0 0}$ \\
\hline
\end{tabular}

Sources: primary data is processed, 2016

From table 2 it appears that sex is the most dominant is female as many as 22 students $(55.0 \%)$ while women were as many as 18 students or $45.0 \%$.

\section{Descriptive Analysis Results}

\section{A. Educative-Preventive Punishment}

Of the 40 respondents found the average score of achievement total of the respondents (TCR) on the provision of educational preventive punishment in the schools is as in table 3 .
TABLE 3. STUDENT PERCEPTIONS ABOUT EDU CATIONAL PREVENTIVE PUNISHMENT GIVEN BY TEACHER AT SCHOOL

\begin{tabular}{|c|c|c|}
\hline No & Items & $\%$ \\
\hline & Educative-Preventive Punishment & \\
\hline 1 & $\begin{array}{l}\text { Late entry on study hours, made to stand } \\
\text { in front of the class for } 10 \text { minutes }\end{array}$ & 34.2 \\
\hline 2 & $\begin{array}{l}\text { None completeness of school uniform } \\
\text { during the ceremony, ranks exiled }\end{array}$ & 31.25 \\
\hline 3 & $\begin{array}{l}\text { unpareyer on Friday for male, punisH to } \\
\text { clean the porch of the office }\end{array}$ & 30.77 \\
\hline 4 & $\begin{array}{l}\text { does not follow the flag ceremony was } \\
\text { punished to clean up the lab / school } \\
\text { library }\end{array}$ & 32.3 \\
\hline 5 & $\begin{array}{l}\text { Do not carry out the task of cleaning the } \\
\text { class, pushed to collect the trash }\end{array}$ & 30.77 \\
\hline 6 & $\begin{array}{l}\text { Students are out more than three times } \\
\text { during the learning process, not allowed to } \\
\text { reenter }\end{array}$ & 31.75 \\
\hline 7 & $\begin{array}{l}\text { Do not wear school uniforms, punished to } \\
\text { push-ups in front of the class }\end{array}$ & 3.15 \\
\hline 8 & $\begin{array}{l}\text { Does not do the work, expended during } \\
\text { school hours }\end{array}$ & 35.4 \\
\hline 9 & $\begin{array}{l}\text { Naughty students were expelled from } \\
\text { school }\end{array}$ & 30.08 \\
\hline 10 & $\begin{array}{l}\text { Fight to the teacher, punished to clean the } \\
\text { assembly room during the week }\end{array}$ & 30.3 \\
\hline 11 & $\begin{array}{l}\text { Exit without permission, suspended one } \\
\text { week }\end{array}$ & 32 \\
\hline 12 & $\begin{array}{l}\text { Coming late to school, punished to take } \\
\text { permit and sentenced to clean the toilet }\end{array}$ & 35.4 \\
\hline 13 & $\begin{array}{l}\text { Untidy dressing, punished to clean the } \\
\text { school yard }\end{array}$ & 27.97 \\
\hline 14 & $\begin{array}{l}\text { Not listening carefully teacher explain, } \\
\text { punished to stand in front of the class up to } \\
\text { the lesson finished }\end{array}$ & 28.4 \\
\hline 15 & $\begin{array}{l}\text { Fight at school, was expelled from the } \\
\text { school }\end{array}$ & 31.91 \\
\hline 16 & $\begin{array}{l}\text { Disturbing friends while studying, } \\
\text { punished to get out of class }\end{array}$ & 29.9 \\
\hline 17 & Cheating in examinations, failing a grade & 30.3 \\
\hline 18 & Doodling school walls, fined Rp. 50.000 & 29.4 \\
\hline 19 & Remove litter, fined Rp. 50.000 & 30.08 \\
\hline \multirow[t]{2}{*}{20} & $\begin{array}{l}\text { Do not listen when the teacher explains } \\
\text { and can not answer the question, punished } \\
\text { to push up in front of the class }\end{array}$ & 29 \\
\hline & & 64.8 \\
\hline
\end{tabular}

According to the table above showed that item 13 was 0.2797 with the level of students Achievement Total in the perception of Educative-Preventive Punishment at 27.97. It showed that the students' response to item 13 is the lowest. Thus it can be said that the students of SDN 06 Nan Sabaris are untidy dressing is not much, meaning that almost all the students are dressed neatly so not too much students who received the punishment of cleaning the school. In Item (8) does not do the work, expended during school hours (12) come late to school were punished to ask permit to the teacher and sentenced to clean the toilet, where the students' perception score was 0.354 with students Achievement Total in EducativePreventive Punishment was $35.4 \%$. these showed that the students' perception of enforcement the preventive educative penalties to item 8 and 12 were the highest, meaning that there are many students who do not do the work, so it should be out during school hours and 
there are many students who come late to school so it was punished to ask permit to related teachers and sentenced to clean the toilet. Thus it can be said that the students of SDN 06 Sabaris still need to be strengthened the discipline in terms of task assignments both at school and at home and building students' character in order to arrive on time to the school.

Overall, the average of students perception toward teacher given Educative-Preventive Punishment was 3:24 with Achievement Total of respondent perception was 64.8. it shows that students' perceptions of the penalties execution for noncompliance in schools have been able to prevent students from undisciplined action.

\section{B. Educative-Repressive Punishment}

Of the 40 students obtained an average score and total achievement of the respondents (TCR) on the provision of Educative-Repressive Punishment in schools is as in table 4.

TABLE. 4 STUDENTS' PERCEPTION ABOUT EDUCA-TIVEREPRESSIVE PUNISHMENT GIVEN BY TEACHERS IN SCHOOLS

\begin{tabular}{|c|c|c|}
\hline No & Items & $\%$ \\
\hline \multicolumn{3}{|c|}{ Educative-Repressive Punishment } \\
\hline 1. & Absent without news, given a warning & 33.9 \\
\hline 2. & $\begin{array}{l}\text { Not doing homework, prompting a letter of } \\
\text { agreement to make a sheet of paperr }\end{array}$ & 34.5 \\
\hline 3. & $\begin{array}{l}\text { Storm during a lesson, warning until punished } \\
\text { to exit from the class by teachers }\end{array}$ & 30.3 \\
\hline 4. & $\begin{array}{l}\text { Leaving school without permission, } \\
\text { prompting to face the teacher }\end{array}$ & 31.3 \\
\hline 5 . & $\begin{array}{l}\text { Not well-dressed reprimanded, punished to } \\
\text { clean the school toilets }\end{array}$ & 31.3 \\
\hline 6. & $\begin{array}{l}\text { Do not accomplish of homework, advised and } \\
\text { called parents }\end{array}$ & 29.9 \\
\hline 7. & $\begin{array}{l}\text { Disturbing friend, advised and asked to } \\
\text { apologize }\end{array}$ & 31 \\
\hline 8. & $\begin{array}{l}\text { Often breaking rules, called a parent and } \\
\text { make an agreement }\end{array}$ & 35.4 \\
\hline 9. & $\begin{array}{l}\text { Sleeping while studying, advised and asked to } \\
\text { get out to wash the face }\end{array}$ & 30.3 \\
\hline 10. & $\begin{array}{l}\text { Talking dirty in school, was reprimanded and } \\
\text { advised }\end{array}$ & 33.1 \\
\hline 11. & $\begin{array}{l}\text { Against a teacher while studying, } \\
\text { reprimanded and advised by teacher }\end{array}$ & 28.37 \\
\hline 12. & $\begin{array}{l}\text { Often fighting with friends, reprimanded, } \\
\text { admonished to be called parents to school }\end{array}$ & 32.8 \\
\hline 13. & $\begin{array}{l}\text { Scribbling on the walls of the school, was } \\
\text { reprimanded and advised }\end{array}$ & 28.78 \\
\hline \multirow[t]{2}{*}{14.} & $\begin{array}{l}\text { Exit without permission of the school, was } \\
\text { reprimanded and warned by the principal }\end{array}$ & 27.21 \\
\hline & Jumlah & 64.3 \\
\hline
\end{tabular}

$\mathrm{Alw}=$ always, $\mathrm{oft}=\mathrm{often}, \mathrm{rar}=$ rarely, $\mathrm{occ}=$ occasionally, nev=never : Sources: primary data is processed, 2016

According to the table above showed that score students' perceptions on item 14 about the enforcement of Educative-Repressive Punishment in school was 0.2721 with Achievement Total of the Respondents was $27.21 \%$. This shows that students' perceptions about the enforcement of Educative-
Repressive Punishment in the case of student's exit without permission, was reprimanded and warned by the principal is lowest. Thus, it can be said that the enforcement of penalties for students who go out without the permission of the school is still in the form of a reprimand and a warning by the principal to the parents.

In Item 8 showed that students' perceptions score was 0.354 with the level of EducativeRepressive Punishment in school was $35.4 \%$. It shows that the students' perception of the enforcement of Educative-Repressive Punishment in school by teachers to this item of the most high. It means that teachers most often provide penalties for students who violate the school rules is to call their parents and tell the students to make the agreement in order not to do the violation of school discipline anymore.

Overall, the average value of student perception about the enforcement of Educative-Repressive Punishment in school was 3:22 with Achievement Total of the Respondents was $64.3 \%$, indicating that students' perceptions about the enforcement of repressive educative penalties at the school of SDN 06 Nan Sabaris Padang Pariaman has been well implemented by the teacher.

\section{Building Students' Discipline Character For Their Future}

Measurement of discipline variables for childhood education is measured prepared with some questions. The greater the average score indicates greater discipline of learning opportunities for children able to face the future of their education. The answer to each question item scale of this discipline are as in the table 5 .

TABLE. 5 STUDENTS' DISCIPLINE CHARACTER FOR THEIR FUTURE

\begin{tabular}{|c|l|c|}
\hline No & \multicolumn{1}{|c|}{ Items } & $\%$ \\
\hline Students' Discipline Character For Their Future & 29.6 \\
\hline 1 & Coming to school early & 30.1 \\
\hline 2 & Working on a school project on time & 28.4 \\
\hline 4 & $\begin{array}{l}\text { Listening carefully to each teacher's } \\
\text { explanations in class }\end{array}$ & 31 \\
\hline 5 & helping a friend who had difficulty in learning & 28.8 \\
\hline 6 & $\begin{array}{l}\text { Together with teachers do the prayers every } \\
\text { day at school }\end{array}$ & 32 \\
\hline 7 & Speaking polite \& respectful to teachers & 31 \\
\hline 8 & Repeating learning at home & 31.3 \\
\hline 9 & Present early class, before class begin & 32.52 \\
\hline 10 & $\begin{array}{l}\text { Glad to discuss and help a friend to understand } \\
\text { the material taught by teachers }\end{array}$ & 30.3 \\
\hline 11 & Ask permission, if cannot come & 34.2 \\
\hline 12 & $\begin{array}{l}\text { Honest and responsible in carrying out } \\
\text { schoolwork and homework }\end{array}$ & 34.8 \\
\hline 13 & $\begin{array}{l}\text { Answer the exam with confidence, not cheat a } \\
\text { friend }\end{array}$ & 31.5 \\
\hline 14 & Accomplish all homework timely & $\mathbf{6 4 . 3}$ \\
\hline & Total & \\
\hline
\end{tabular}


Note:

$\mathrm{Alw}=$ always, $\mathrm{oft}=\mathrm{often}, \mathrm{rar}=$ rarely, $\mathrm{occ}=$ occasionally, nev $=$ never Sources: primary data is processed, 2016

According to the table 3 above showed that item 3 about Students' Discipline Character Building For Their Future amounted to 0.284 with the level of Achievement Total of the Respondents was 2.84. This shows that the formation of students' discipline character for their future education for item 3 is lowest, meaning that not all students are currently taking place in the classroom lessons are always listening their teacher's explanation carefully when the teacher explains the material in front of the class. For that teachers should develop strategies of learning more and more so that students are motivated to listen teachers' explanation carefully during the learning process due in the classroom so that students master the material submitted by teacher well

In Item 12 appeared that perception scores of students in terms of implementation of discipline in schools was 0,348 with the level of Achievement Total of the Respondents was 34.8. This showed that the formation of students' discipline character for their future education in item 12 is highest, meaning that most students be honest and responsible in carrying out their school assignments and homework given by their teachers. For that teachers should strengthen students' discipline character and enrichment students' learning process as well as strengthening students' understanding of matter through the provision of schoolwork and homework provided with an sustainable evaluation, so the teacher can monitor the progress of students' learning behavior constantly that allows teachers to build their character achievement, honesty and discipline. Overall, the average value of students' discipline character was 3:21 with Achievement Total of the Respondents was $64.3 \%$, meaning that the students' discipline character development to face their future education will be much better

\section{Inferential Analysis Results}

Multiple Regression Analysis was obtained the estimation results as shown in the table 6 .

TABLE. 6 RESULTS ANALYSIS OF THE PUNISHMENT EFFECT TOWARD STUDENTS' DISCIPLINE

\begin{tabular}{|l|c|c|c|}
\hline \multicolumn{1}{|c|}{ Variable } & $\begin{array}{c}\text { Rregresio } \\
\mathrm{n} \\
\text { Coofecie } \\
\mathrm{nt}\end{array}$ & $\mathbf{T}_{\text {count }}$ & Significant \\
\hline Constant & 58.192 & 3.641 & 0.012 \\
\hline $\begin{array}{l}\text { Educative Preventive } \\
\text { Punishment (X1) }\end{array}$ & 250 & 3.062 & 0.046 \\
\hline $\begin{array}{l}\text { Educative Repressive } \\
\text { Punishment (X2) }\end{array}$ & 0.610 & 3.709 & 0.010 \\
\hline $\mathrm{F}_{\text {account }}$ & 11.850 & & 0.000 \\
\hline $\mathrm{R}^{2}$ & 0.723 & & \\
\hline
\end{tabular}

Sources: primary data is processed, 2016
From Table. 5 can be formulated the model estimates the effect of educative preventive and repressive punishment to students' discipline characters of SDN 06 Nan Sabaris Padang Pariaman are:

$$
\mathrm{Y}=58.192+250\left(\mathrm{X}_{1}\right)+0.610\left(\mathrm{X}_{2}\right)+\mathrm{e}
$$

From the results of multiple regression analysis was obtained the coefficient as explained by the following analysis:

a. Regression coefficient of Educative-Preventive Punishment $\left(\mathrm{X}_{1}\right)=2.062$, this showed the influence of preventive punishment to students' discipline characters for building their education for the future. A positive sign indicates a positive correlation coefficient of direction. Meaning every increase of one unit variable of EducativePreventive Punishment, students' discipline characters for building their education for the future will increase by 2.062 units assuming other factors are constant.

b. Regression coefficient of Educative- Repressive Punishment $\left(\mathrm{X}_{2}\right)=2.709$, showed the magnitude of the influence of preventive punishment to students' discipline characters for building their education for the future. This variable showed a positive relationship between EducativeRepressive Punishment toward students' discipline characters for building their education for the future where if Educative- Repressive Punishment increase 2.709, it will increase students' discipline characters for building their education for the future by 2.709 , assuming other factors constant.

The regression result showed that the coefficient value of determination $\left(\mathrm{R}^{2}\right)$ was 0.723 , it means that $72.3 \%$ of the dependent variable (students' discipline character building for future the education) is influenced by independent variable (educativepreventive and repressive punishments) and 27.7\% was influenced by other factors outside the study with significant level of $F_{\text {count }} 11.850$. It means that educative-preventive and repressive punishments stimultenously have a significant influence on the students' discipline.

The result of significant t-test for educativepreventive punishment is 0.046 , it means that educative-preventive punishment has significant effect with students' discipline for their future education. While For educative-repressive punishment obtained t-test 0.010 , it means that educative-repressive punishment also has significant effect toward students' discipline.

From these results it appears that the majority of teachers at SDN 06 Nan Sabaris Padang Pariaman are still adopting a educative-preventive punishment directly to the violation of school rules in accordance with the error rate ranging from corporal punishment such as stand up in class, push-ups, Scots jump for 
those who do not accomplished the homework, clearing room of teachers, cleaning toilets for coming late to school, fined Rp. 50,000 for students who scribble on the walls of the school, punished to clean the school grounds for students who neglect the rubbish, go out from the class if students do not accomplish their school-task or home-tasks and even will be exile from the school when naughty and unruly.

While the application of educative repressive penalties in the nature of guiding students in order not to longer violate the established rules of school is to provide the penalties of warning, advice, and having students make the agreement up to call their parents to work together to monitor student behavior, in order not to repeat the violation of rules in the future. Model of giving repressive punishment is by giving the educative punishment in order to improve student behavior so that it no longer violates school rules or enforce the students' discipline to support the educational success of their future.

For that reason, it can be said that the punishment by teachers on students in the classroom have to be giving physical punishment as established by the school to prevent students are afraid to break the rules because it is responsible for the undisiplined behavior that must be followed if found violating rules ranging from mild sanctions of physical punishment like standing in class, push-ups, Scots jump for who are not doing homework, cleaning the teacher's room, cleaning toilets, cleaning the school yard, pay the fine, until the exile of schools if students break the rules of school in accordance with the mistaken level made by the students.

Teachers must continue to execute the educative-repressive and preventive punish-ment at the same time by giving idle behavior and advice to students about school rules that must be obeyed and the punishment given to those who abuse and harsh sanctions that would be given if they abuse. By this way the students will try to avoid things that can cause them to breach of discipline in schools, due to the high level of consciousness will awaken the character of student discipline honest, tenacious, hard working, responsible, appreciate to friends, respect to teachers and comply with school's regulations thus supporting the educational success of students in the future.

The students' perceptions about the execution of preventive and repressive punishment by building the students' discipline character in facing future education better have been applied well by teacher at the school SDN 06 Nan Sabaris Padang Pariaman, where teachers provide exemplary of the present in class on time, study time should not be noisy, should not be fighting, and called their parents as a comprehensive form of punishment between schools and parents to children. By enforcing the discipline and sanctions to undisciplined students in accordance with the established rules of school, it will be able to build students' discipline character strongly inside of individual students in order not to commit breaches of discipline and respect all school regulations, at least, majority of students said always perform their tasks and activities consciously in the school refer to established rules of school, obey and compliance with all provisions established, both written and unwritten regulations, they respond gladly, willingly and responsibilities into capital of personality character formation of superior that are useful for their future education.

Ths study can colude that the execution of punishment can strengthening students' discipline with the average index of each students' discipline are 3:34 and 3:22, with the level of Achievement Total $64.8 \%$ and $64.3 \%$ respectively. From the calculation of determinant coefficient of preventive and repressive punishment contributed $72.3 \%$ to the development of student discipline characters for their future education. There is significantly affect between preventive and repressive punishment Toward the development of students' discipline for their future education.

The implications of study for teachers are to execute the punishment for students who violate the discipline rule as suitable as their infringement of rule by using particular technique in the form of educative punishment with age-compromised which gradually enable to improve their future education discipline.

\section{ACKNOWLEDGEMENT}

This research was supported by State University of Padang. We thank our collea-gues from Rasyidah of STIT Syekh Burha-nuddin Pariaman who provided insight and expertise that greatly assisted the research. We thank to Zelhendri Zen for assistance with particular technique, methodology, and Reflianto, Chief of LP2M STIT Syekh Burhanuddin Pariaman, for comments that greatly improved the manuscript.

\section{REFERENCES}

[1] Apriliya. Manajemen Kelas Untuk Menciptakan Iklim belajar Yang Kondusif, Jakarta: PT Visindo Media Persada; 2007.

[2] Brown, B. Perception of student misconduct, perceived respect for teachers, and support for corporal punishment among school teachers in South Korea: an exploratory case study. Education Research for Policy and Practice, volume 8 (1), 2009; 3-22.

[3] Rosen, L. School Discipline: Best Practices for Administrators. California: Crowin Press, Thousand Oaks; 1997.

[4] Skinner, B. F. The Technology of Teaching. New York: Appleton-Century-Crafts; 1968.

[5] Evertson, C. M. and Emmer, E. T. Effective management at the beginning of the school year in junior high classes Journal of Educational Psychology, 1982; 24: (4), 485-498.

[6] Gungor, S. Sinıf disiplini. (Ed.İkram CINAR), Sınıf Yonetimi, Ankara: Anı. Bilimler Enstitusu Dergisi, 2014; 16 (1) : 539-560. 
[7] Ugulu, C.T. Sinıfta zaman yonetimi. Sinıf Yonetimi, Ankara: Egiten Kitap; 2014

[8] Lewis, R. The discipline dilemma (2nd ed.) Australia: The Australian Council for Educational Research. Melbourne; 1997a.

[9] Lewis, R.. Discipline in schools. In L. J. Saha (Ed.), International encyclopedia of the sociology in education (pp. 404-411). Oxford: Pergamon; $1997 \mathrm{~b}$.

[10] Swinson, J., \& Melling, R. Assertive discipline: Four wheels on this wagon-Areply to Robinson and Maines. Journal of Educational Psychology in Practice 1995; 11(3): 3-8.

[11] Swinson, J. \& Cording, M. Assertive Discipline in a school for pupils with emotional and behavioural difficulties. British Journal of Special Education, 2002; 29(2): 72-75.

[12] Freiberg, H. J. From tourists to citizens in the classroom. Journal of Educational Leadership, 1996; 54(1): 32-36.

[13] Pearl, A., \& Knight, A. Democratic schooling: Theory to guide educational practice. New Jersey: Hampton Press; 1998.
[14] Schneider, Giving students a voice in the classroom. Journal of Educational Leadership, E. 1996; 54(1): 22-26

[15] Gershoff, E.T. Corporal punishment by parents and associated child behaviours and experiences. A metaanalytic and theoretical review. Psychological Bulletin, 2002; 128: 339-579.

[16] Hugo, Adam Bedau. "Punishment, Crime and the State". Stanford Encyclopedia of Philosophy; 2010. Retrieved 2017-08-04

[17] McAnany, Patrick D. "Punishment". Online. Grolier Multimedia Encyclopedia, 2010.

[18] McAnany, Patrick D. "Justification for punishment (Punishment)". New York: Appleton-Century-Crafts; 2010.

[19] Peters, Richard Stanley Ethics and Education. JSTOR 3120772; 1966: 267-268.

[20] Mary Stohr; Anthony Walsh; Craig Hemmens. Corrections: A Text/Reader;2008; Retrieved 2017-08-04 